\title{
Politics in Christian missions
}

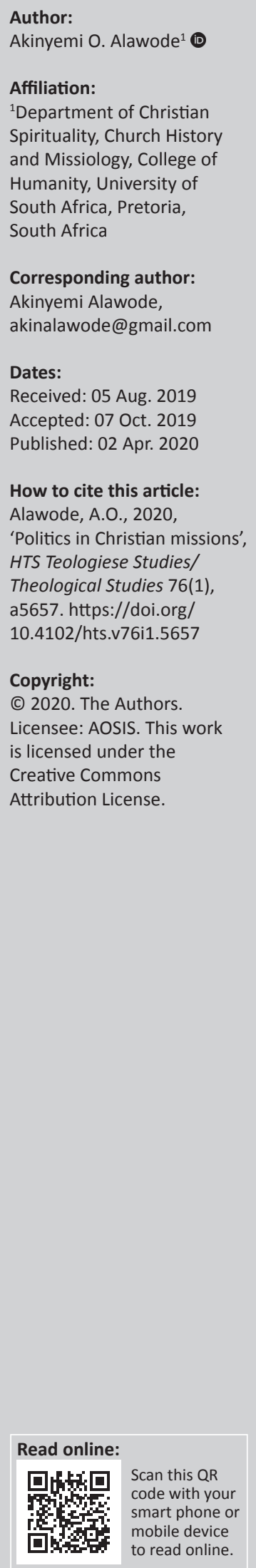

For decades, the mobilisation of Christian missions has encountered a number of setbacks and barriers because of several factors and elements that pose severe impediments to the conduct of missionary activities. Amongst these factors and elements, the involvement of politics in the activities of the Christian missions is prominent. The goal of the Christian missions is to expand the kingdom of God, as well as the salvation and restoration of lost souls, while the goal of politics is to secure power and authority through manipulation for selfish interests or gains. A Christian mission seeks spiritual and heavenly fulfilment, while politics seeks mundane and worldly gains.

Keywords: Christian missions; missionary; heavenly fulfilment; politics; worldly gains.

\section{Introduction}

It is evident that Christian missions and politics are of different directions, but unfortunately politics has made its way into the activities of the Christian missions, and the result has always been setbacks, barriers and impediments in the missionary endeavours (Aboague-Mensah 1994:22). Politics is the procedure of making decisions that apply to the members of a group. It refers to achieving and exercising a position of governance, which is organised control over a human community, particularly a state (Hiebert 1995). Politics also includes the struggle between different groups of people (ethnic, religious or class) to have the ultimate power in a more significant group (Kukah 2011:145). According to Kukah, politics is associated with propaganda, war and violence, deception, struggle and strife. The author further stated that politics is useful in political science and state governance but is not ideal for religion or Christian activities (Kukah 2011).

Christian mission is to follow the call of Christ, that is, sharing the good news with the lost world through God's wisdom, strength and empowerment of the Holy Spirit (Musa 2009:137). It has to do with obedience to Christ's command and mandate. After the death and resurrection of Christ, he commanded his disciples to share the good news of salvation and redemption with the unsaved world:

$[T]$ herefore go and make disciples of all nation, baptising them in the name of the Father and of the Son, and of the Holy Spirit, and teaching them to observe everything I have commanded you, and surely I am with you always to the very end of the age. (Mt 28:19-20)

The result of the involvement of politics in Christian missionary activities forms the basis of this article. Therefore, in this study, the author looks at the involvement of politics in the Christian missionary enterprise to proffer a lasting solution by reviewing the historical overview of Christian missions, politics in Christian missions and the effects of politics on Christian missions, and makes adequate recommendations before the conclusion.

\section{Historical overview of Christian missions}

Christian missionary enterprise has to do with following Christ's call of sharing the gospel with the lost world through God's wisdom and strength (Musa 2009:137). After Christ's death and resurrection, he commanded his disciples to share the good news of redemption to the lost world. The command forms the basis or background for the Christian missions to the world.

Given this, Conn and Ortiz (2001:459) asserted that the mission movement of the New Testament was primarily an urban movement void of politics. According to them, after the Pentecost, the mission of Christ spread from the city to the surrounding countryside. This missionary was intended to expand the kingdom of God. Significantly, the predominant drive of the ministry of Jesus was in the centre of his time following the testimony of Matthew 9:35-36. 'And Jesus went about all the cities and villages, teaching in their synagogues and preaching the gospel of the kingdom and healing every disease and every infirmity' (Mt 9:35-36). 'Jesus instructed the apostles to tarry in the city of Jerusalem until they were endowed with power from on high for missions' (Lk 24-49). 
There was intense determination in the ministry of the apostles regarding the mobilisation of Christian missions. According to Ukaeke (2008:13), the apostles followed, together with the principles of church expansion, the development and disciple communities of believers, thereby covering cities and nations with the gospel.

The mission of the Apostles in Antioch of Syria was another unusual move in the history of Christian mission. Greenway (1999:14) stated that the Christian missions commissioned missionaries and sent them out to evangelise the world from the church in Antioch, which later became the mother church for Christian missions in the Apostolic Era.

The earliest examples of the history of Christian missions are those recorded in the letters that formed the New Testament, which included the letters of Apostle Paul written when he was in Asia Minor and Greece for his missionary activities. The activities of these missions were preceded by the expansion of the first followers of Jesus in Jerusalem throughout Syro-Palestine as was recorded in the Acts of the Apostles (Greenway 1999). The missionary activities in the Apostolic Era gave rise to the development of Christian missionary enterprise in the early church.

\section{Mission in the early church}

The expansion and growth of the small group that met in the 'upper room' during the Apostolic Era in Jerusalem resulted in the activities of the missions that moved like wildfire at the beginning of the era of the early church (Terry, Ebbie \& Justice 1998:166). In 325, Emperor Constantine and Bishop Hosius welcomed 318 bishops to the Council of Nicaea to discuss and seek ways to expand the mandate of the Christian missions to the lost world (Terry et al. 1998). This led to the expansion and growth of Christian missions to other parts of the world, as the early church followed actively in their tradition the examples of some early apostles like Thaddeus who ministered in Edessa, Mark who founded the church in Alexandra, Peter who ministered in Bithynia and Cappadocia, Paul in Spain and Thomas in India.

The mission in the early church extended to other parts of the world as a result of the outcome of the discussion reached at the Council of Nicaea by the bishops to take the mission as a corporate mandate of the church to reach the world for Christ. Given this, Emperor Constantine and his son Constantius encouraged the expansion of Christian missions and the growth of Christianity by instituting Christianity as a way of maintaining peace within the empire and pacify warlike tribe outside its borders (Terry et al. 1998).

\section{Missions in the medieval and renaissance periods}

During the medieval and renaissance periods, the destiny of Christian missions changed because of the negation of many gains in the first century. Christianity won Northern Europe, but it practically lost all of North Africa, Southeastern Europe, most of Asia Minor, Syria and Palestine as a result of a confrontation with Islam (Hiebert 1995:374). Fortunately, for Christianity, the rise of protestant reformation brought about spiritual and biblical revival and reawakening to both Roman Catholics and Protestants with regard to inner vitality for Christian mission, which led to the emergence of courageous missionaries who dared to penetrate hostile areas (Hiebert 1995). As a result, the monastic and missionary order became proactive; the universal nature of the reformed faith became a factor in this turnaround. This era prepared the way for the modern mission movement.

\section{History of Christian missions in Nigeria}

The history of Christian missions in Nigeria dates back to the 15th and 16th centuries AD when some Portuguese traders and missionaries came to the shores of Nigeria with the primary aim of trading (Fatokun 2013:132). These trade activities opened the channel for evangelism, and made new converts; however, this enterprise experienced a miscarriage, as it could not establish a permanent and robust Christian foundation in Nigeria. Because of the failure of the Portuguese missionaries to establish Christianity and Christian missions in Nigeria, Christian mission was replanted in Nigeria in 1842 by the Methodist Mission (Awojobi 2013:322).

This reintroduction witnessed tremendous growth and expansion as many adherents of traditional religion converted to Christianity.

After this, Nigeria witnessed the emergence of several mission groups like the Roman Catholic mission, the Church Missionary Society, the Methodist Mission, the Church of England (Anglican) Mission and the Baptist Mission, which were playing leading roles in advancing the frontiers for Christian missions' education in Nigeria (Fabunmi 2013:142).

\section{Politics in Christian missions}

The exercise of politics in any society, group, organisation and leadership is to acquire power, control and manipulation. It is evident that politics has much in common with government and law, but it has extended several aspects to the society, including the church and mission. Hiebert (1995:17) stated that politics is the acquisition and use of power, manipulation and leadership within a group or society (Fabunmi 2013). The historical relationship between Christian missions and politics has led to several conflicts in Christian missionary activities. Mission leaders were controlled often by political influence rather than missiological and Christian principles (Gwamna 2010:46). Politics performs the functions of adaptation, integration and allocation of human and material resources. It deals with the form, organisation and administration of a state or nation, and also regulates their relations with other nations in terms of principles, opinions and administration (Dzurgba 2008:2). 
There has always been a conflict between politics and Christian missions where politics seeks to play a controlling role in the essential principles of Christian missions in any particular nation or state. After the acceptance of Christianity by Emperor Constantine, the balance shifted in favour of the church, and the church assumed political power (Dzurgba 2008). This absorption of Christianity into the state gave rise to the contribution of political leaders in the decision-making of the principles and activities of the Christian missions. It is notable here that the nature of politics was characterised by personal interest and desire, and it does not consider the feelings of others. It dominates, manipulates and overrules issues with power and authority, not minding the effects on others (Okoroji 2004:20).

Uzoeshi (2012:159) stated that Christian missionary enterprise experienced a number of setbacks and barriers because of church politics, which has been brought into the activities of the missions in recent times. According to him, these political barriers are seen clearly in the way mission activities are carried out in several mission fields, both at home and internationally. The politics of ethnicity, personality, tribalism and national interests, which are prominent in the setback for the activities of Christian missions, elaborated for a clearer understanding of the role of politics in Christian missions.

Political leadership is key to national development and also paves the way for positive and sustainable development. The greatest developmental achievement of Christian missions predicated on the strong Christian belief held by the founding fathers, most of whom had some theological training (Dockery 1993:27). Given this, there comes a prominent question, why is there such a vast gulf between Christian missions and politics? The answer to this question will set the foundation for the rest of this research work.

\section{Effects of politics on Christian missions}

As stated earlier, some church members who have seen the church as a platform to exhibit their political knowledge have politicised several activities of the church, including mission. This action has resulted in conflicts and complications, which hurt the mandate of Christian missions:

1. One of the effects of politics on the Christian missions is the idea of church members seeing themselves as 'constitutional or traditional' members of the church (Uzoeshi 2012:160). These members see their membership of any church as a political, constitutional or traditional right. Therefore, they resist any move to relocate them to another place for church expansion. For them, the local church remains a traditional and political inheritance for worship and therefore they must not leave for another place. Politics in Christian missions had made it very difficult to mobilise for church expansion (Uzoeshi 2012). Many of these members prefer coming to church from a long distance rather than accepting the challenge and encouragement of the Mother Church to plant a new church closer to where they live. Most times, this action brings discouragement to several hearts that are willing to stand for Christian missions and church expansion.

2. Another effect of politics on Christian missions is conflict and crisis. Conflict and crisis is a primary weapon of the devil against the goals and expectations of the Christian missions (Uzoeshi 2012). Politics is strongly associated with risis, and Satan uses it against the goals and efforts of the church for mission mobilisation. When politics enters the church, it brings conflicts, and conflicts result in internal disagreement and spiritual bitterness amongst the members and leaders of the church, thereby promoting spiritual and physical disintegration against the accomplishment of the vision of Christian missions (Uzoeshi 2012). It is notable here that most churches planted through crisis and conflict always breed ungodly competition, strife and unforgiveness, and this is very dangerous and detrimental to the proper propagation of the gospel (Uzoeshi 2012).

3. Another effect of politics on Christian missions is the lack of adequate application of the word of God amongst church members. The attention of the church members would be diverted from spiritual matters to mundane things when politics enters the church. The church will no longer give adequate attention to the word of God; instead, personal and selfish interests will occupy the heart of the people, and mission activities will receive setbacks. Giving little or no attention to the living word of God, which is the food of souls, will lead to a decline in the mandate for Christian missions and moral degradation (Conn \& Ortiz 2001:89).

4. Another effect of politics on Christian missions is the lack of adequate financial and material support for mission work. Any time the efforts of Christian missions are politicised, the release of financial and material resources for mission work becomes a political and debatable issue. One faction may agree on giving support to missions while the other faction may disagree (Aboague-Mensah 1994:32).

5. As a result of the politics in Christian missions, the engagement of some mission officers was carried out by the desire of their 'godfathers' and not by the leadership of the Holy Spirit. As a result, people who have little or no knowledge about Christian missions are engaged to run the affairs of the mission efforts of the church (Aboague-Mensah 1994).

6. Another effect of politics on Christian missions is the promotion of ethnic and tribal rivalry. Whenever Christian missions are politicised, activities will no longer be on the directive and leadership of the Holy Spirit, and it will hurt tribal and ethnic interests. Each tribe and ethnic group in the church will be lobbying for the church to direct church attention to their ethnic interests. When this happens, the aim of the Christian mission, which is soul winning and expansion of God's kingdom, will be diverted to something else (Musa 2009:145).

Enumerating the effects of politics on Christian missions, the researcher now recommends some steps that Christian 
missions should take into account in order to achieve their expected aim.

\section{Recommendations}

As politics does no good to the work of mission, the author recommends the following steps that should be taken into account in order to avoid politics in the Christian mission:

Love: The body of Christ should exhibit love amongst themselves. When the love of God is in the lives of believers, there would be no room for selfish or personal desire.

Discipleship: The church should take discipleship very seriously because it is the means of building responsible Christians. When believers become responsible, they will give no room to the things of the flesh; instead, they will go for spiritual issues that can encourage them to carry out the mission of God.

Ethnic and tribal barrier: Ethnic and tribal differences should be discouraged in the body of Christ because it gives a platform for politics in the church.

The goal of believers for the Christian missions should be the sharing of Christ's good news of salvation. Christian missions should be the proclamation of Christ as the only saviour from sin and the only way to abundant and eternal life. Believers should rely on Christ and allow the Holy Spirit to freely manifest amongst them as they carry out the activities of the missions.

\section{Conclusion}

Politics, in its nature, is characterised by personal interests and selfish desires, and it does not consider the interests of others. However, there are some exceptional cases where politics was used for the betterment of humanity; for example, William Wilberforce, the author of Real Christianity, used politics to abolish slave trade in England.

This is a good example of very few situations in which politics was engaged for human benefit. However, to a larger extent, politics dominates, manipulates and overrules issues with power and authority without considering the effects on others. Moreover, in order not to experience barriers and impediments because of the involvement of politics, which does not blow good wind to Christian missionary activities, Christians should carry out the mandate of the Christian mission with love, void of politics, and allow the Holy Spirit to take the lead for effective fulfilment. The work of mission should be performed with love and not with politics, 'for the love of Christ compels us ...' (2 Cor 5:14).

\section{Acknowledgements}

I wish to express my gratitude to the Lord, Almighty for his grace upon my life, also I appreciate my wife Mrs Oluwatoyin Wumi Alawode for her support.

\section{Competing interests}

The author has declared that no competing interest exists.

\section{Author(s) contributions}

I declare that I am the sole author of this research article.

\section{Ethical consideration}

This article followed all ethical standards for a research without direct contact with human or animal subjects.

\section{Funding information}

This research did not receive any specific grant from funding agencies in the public, commercial or not- for-profit sectors.

\section{Data availability statement}

Data sharing is not applicable to this article as no new data were created or analysed in this study.

\section{Disclaimer}

The views and opinions expressed in this article are those of the author and do not necessarily reflect the official policy or position of any affiliated agency of the author.

\section{References}

Aboague-Mensah, R., 1994, Mission and democracy in Africa: The role of the Church, Asempa Publishers, Accra.

Aderinto, O., 2014, Nigeria yesterday, today and beyond: Prophetic journey of a century, Baptist Press Nig. Ltd., Ibadan.

Awojobi, P., 2013, Christian persecution in Northern Nigeria, Book Wright Publishers, lbadan.

Conn, H.M. \& Ortiz, M., 2001, Urban Ministry: The kingdom, the city, and the people of God, Intervarsity Press, Downers Grove, IL.

Dockery, D., 1993, Southern Baptists and American Evangelicals, Broadman and Holman Publishers, Grand Rapids, MI.

Dzurgba, A., 2008, Nigerian politics and ethical behavior, John Archers Publishers, Ibadan.

Epps, D. (ed.), 2005, The churches in international affairs: Report 1999-2002, World Council of Churches Press, New York.

Fabunmi, S.K., 2013, Christianity and education development in Africa: A comparative study of Nigeria and Sierra Leone, Book Wright Publishers, Ibadan.

Fatokun, S., 2013, The role of Christianity in the development of West Africa: The Nigerian experience in Christianity and African Society, Book Wright Publishers, Ibadan

Greenway, R., 1999, Go and make disciples, P and R Publishing, Philipsburg.

Gwamna, D., 2010, Religion and politics in Nigeria, African Christian Textbooks, Bukuru.

Hiebert, P., 1995, Cultural Anthropology, Baker Book Publishers, Grand Rapids, MI, viewed 08 November 2017, from http://www.brictannica.com.politcs.

Kukah, M., 2011, Religion, politics, and power in Northern Nigeria, Spectrum Books Limited, Ibadan.

Musa, D., 2009, Christians in politics, how can they be effective?, African Christian Textbooks, Bukuru.

Okoroji, J., 2004, Christian and politics: A New Testament perspective, Ronke-Prints, Warri.

Terry, J., Ebbie, S. \& Justice, A. (eds.), 1998, Missiology: An introduction to the foundations, history, and strategy of world missions, Broadman and Holman Publishers, Nashville, TN.

Ukaeke, B., 2008, Church planting and development, Oludare Nigeria Enterprise, Lagos.

Uzoeshi, U., 2012, Mission shift: Mobilizing through urban church planting, Alphabet Nig. Publishers, Owerri. 